ICTD Working Paper 7

Local Government Revenue Mobilisation in Anglophone Africa

Odd-Helge Fjeldstad and Kari Heggstad

October 2012 
Local Government Revenue Mobilisation in Anglophone Africa

Odd-Helge Fjeldstad and Kari Heggstad

ICTD Working Paper 7

First published by the Institute of Development Studies in October 2012

(C) Institute of Development Studies 2012

ISBN 978-1-78118-090-7

A catalogue record for this publication is available from the British Library.

All rights reserved. Reproduction, copy, transmission, or translation of any part of this publication may be made only under the following conditions:

- with the prior permission of the publisher; or

- with a licence from the Copyright Licensing Agency Ltd., 90 Tottenham Court Road, London W1P 9HE, UK,

or from another national licensing agency; or

- under the terms set out below.

This publication is copyright, but may be reproduced by any method without fee for teaching or nonprofit purposes, but not for resale. Formal permission is required for all such uses, but normally will be granted immediately. For copying in any other circumstances, or for reuse in other publications, or for translation or adaptation, prior written permission must be obtained from the publisher and a fee may be payable.

Available from:

Communications Unit

Institute of Development Studies,

Brighton BN1 9RE, UK

Tel: +44 (0) 1273915637 Fax: +44 (0) 1273621202

E-mail: bookshop@ids.ac.uk

Web: www.ids.ac.uk/ids/bookshop

IDS is a charitable company limited by guarantee and registered in England (No. 877338) 


\title{
Local Government Revenue Mobilisation in Anglophone Africa ${ }^{1}$
}

\author{
Odd-Helge Fjeldstad and Kari Heggstad
}

\section{Summary}

This paper examines opportunities and constraints facing local revenue mobilisation in anglophone Africa, with an emphasis on urban settings. It discusses specific revenue instruments and their effects on economic efficiency, income distribution and accountability. In particular, it addresses political and administrative constraints facing various revenue instruments and factors affecting citizens' compliance. The analysis is illustrated with examples from across anglophone Africa. A general conclusion emerging from the study is that local revenues mobilised in most local government authorities in Africa are necessary but not sufficient to develop and supply adequate services for the fast-growing population. On this basis, areas for further research on local government revenue mobilisation in Africa are identified.

Keywords: local government, decentralisation, taxes, business licences, user fees, Africa

Odd-Helge Fjeldstad is an economist (Dr. Oecon) with more than 25 years of experience of research and policy analysis in Eastern and Southern Africa and the Middle East. He has published widely on taxation, both scholarly and policy-oriented. Thematically his work can be grouped into three main areas: (i) tax evasion and fiscal corruption; (ii) taxation and statebuilding; and (iii) local government taxation and financial management. Odd-Helge has considerable experience in research management, and has served as a director of major multidisciplinary research and training programmes, including the U4 Anti-Corruption Resource Centre. Currently, he is Senior Researcher at Chr. Michelsen Institute in Norway, and Research Director of the International Centre for Tax and Development (ICTD).

Kari K. Heggstad is a political scientist whose research interests relate to taxation and state building, revenue administration, tax evasion and financial crime. While contributing to this paper, she was employed as a research officer at Chr. Michelsen Institute and the International Centre for Tax and Development. Kari has also been a staff member of the Botswana Institute for Development and Policy Advice (BIDPA) and Bergen University College.

This paper was prepared for the inception phase of the International Centre for Tax and Development (ICTD). We would like to thank Olav Lundstøl, Stephen Peterson, Ingrid Hoem Sjursen and an anonymous reviewer for constructive comments on earlier drafts. Points of view and possible errors rest entirely with the authors. 


\section{Contents}

$\begin{array}{ll}\text { Introduction } & 5\end{array}$

1. Tax assignment rules and fiscal transfers $\quad 6$

1.1 Who levies which taxes? 6

$\begin{array}{lll}1.2 & \text { Transfers from central government } & 7\end{array}$

$\begin{array}{ll}\text { 2. Features of local government tax systems } & 11\end{array}$

3. Local government 'own revenue' instruments 13

3.1 Property tax 14

$\begin{array}{lll}3.2 & \text { Business licences } & 19\end{array}$

3.3 User fees - linking payment and service delivery 23

$\begin{array}{ll}\text { 4. Local government tax collection practices } & 25\end{array}$

5. Concluding remarks and tentative implications for policy 27

$\begin{array}{ll}\text { 6. Issues for further research } & 29\end{array}$

$\begin{array}{ll}\text { References } & 31\end{array}$

Boxes

Box 1 Intergovernmental transfers in South Africa 8

Box 2 Unconditional grants to local governments in Ghana and Uganda 9

Box 3 Reforming the local government revenue system in Tanzania 13

Box $4 \quad$ Property taxation and political engagement in Kenya 16

Box $5 \quad$ The property tax base in anglophone West Africa 17

$\begin{array}{lll}\text { Box } 6 & \text { Deficient property tax administration in Kampala } & 18\end{array}$

$\begin{array}{lll}\text { Box } 7 & \text { The Single Business Permit (SBP) in Kenya } & 21\end{array}$

Box 8 Streamlining business registration in Entebbe municipality, Uganda 22

Box $9 \quad$ Free services to the poor in South Africa 23

Box 10 Improving compliance through shared private water taps in

Ondangwa, Namibia 24

Figures

Figure 1 Intergovernmental transfers as percentage of total local revenue In some East and Southern African countries (2007) 9

Figure 2 Property tax reform in a selection of anglophone African countries 15

Figure 3 Rents in tendering contracts for a rural market in Uganda 27

Table

Table 1 Types of property tax in anglophone Africa 


\section{Introduction}

A sound revenue system for local governments is an essential pre-condition for the success of fiscal decentralisation (Bird 2010; Martinez-Vázques and Smoke 2010a; Olowu and Wunsch 2003). In addition to raising revenues, local revenue mobilisation has the potential to foster political and administrative accountability by empowering communities (Shah 1998; Oates 1998). However, prescriptions deriving from the theory and from accepted international practice impose huge constraints on the choice of revenue instruments for local governments.

The growth of Africa's population has outpaced local authority capacity for service delivery in terms of management, infrastructure, and financing (McCluskey et al. 2003: 3; McCluskey and Franzen 2005: 43-44). Firstly, urban municipal authorities, many of which were originally instituted as colonial administrative institutions, have not been restructured to cope with the fast-growing population (Beall 2000). Secondly, a growing number of residents live in informal settlements with inadequate basic services such as housing, clean water, electricity, sanitation, refuse collection, roads, and transport (Devas 2003). Thirdly, many local government authorities are financially weak and rely on financial transfers and assistance from central government (Brosio 2000). Moreover, local government tax administrations are often inefficient and not able to properly account for revenues collected (Fjeldstad 2006).

As a result, many local governments in Africa are facing a governance crisis and poor service delivery capability. Fiscal decentralisation - the devolution of revenue mobilisation and spending powers to lower levels of government - has become a main theme of local governance in recent years. The purpose of this paper is to examine opportunities and constraints facing local revenue mobilisation in anglophone Africa, with a focus on urban settings. ${ }^{2}$ It discusses the various instruments available, their revenue potential, and how they affect economic efficiency, income distribution and accountability. The paper also addresses political and administrative constraints facing local revenue mobilisation, and factors that affect citizens' compliance. The emphasis is on local government 'own revenue', but fiscal transfers from the central level are also covered. The paper argues that local governments need to be given access to adequate resources to do the job with which they are entrusted. However, the revenues mobilised by most local authorities in Africa are generally not sufficient to develop and supply adequate services for the fast-growing population. Hence, a general conclusion that emerges from the study is that local own revenues are a necessary but not a sufficient condition for fiscal decentralisation.

The paper is organised as follows. The first section provides a brief review of the established rules of tax assignment between levels of government, and key features of intergovernmental fiscal transfer systems in anglophone Africa. Challenges facing the reform of local government revenue systems in Africa are discussed in Section 2. Section 3 focuses on the strengths and weaknesses of the major local 'own revenue' instruments, particularly property tax, business licence and user fee regimes. Methods for revenue collection are addressed in Section 4 . Section 5 concludes by outlining some policy implications. The final section identifies areas for further research based on the previous analysis. 


\section{Tax assignment rules and fiscal transfers}

In general, there are two main sources of revenue for local government authorities (LGAs) in Africa: (i) own revenue, which includes taxes, user fees, and various licences (Bahl and Bird 2008); and (ii) transfers from the central or regional levels, usually in the form of grants and revenue sharing (Bahl and Smoke 2003: 71). In some countries municipalities are allowed to borrow in order to finance investments in local capital infrastructure (Yatta and Vaillancourt 2010: 42; Bahl and Smoke 2003: 8). ${ }^{3}$ This section briefly reviews some general principles for revenue assignment between different levels of government, and discusses challenges to securing fiscal responsibility at subnational levels with respect to intergovernmental transfer systems.

Although other revenue sources may exist at subnational levels, these are not covered by this study. For instance, external financial contributions provide considerable funding to constituencies at village and local level in some countries. These sources are dominated by aid projects or programmes funded by a mix of international non-governmental organisations, bilateral and multilateral donors (Yatta and Vaillancourt 2010; Fjeldstad 2001). Often the local government has little or no knowledge of such projects at either the planning or execution phase. In many rural areas, various forms of self-help activities contribute to the maintenance of public services, such as village roads, primary schools and health facilities. Although data on the extent of self-help activities is not available, studies from Tanzania in the 1990s indicate that these contributions are significant (Cooksey and Mmuya 1997; Semboja and Therkildsen 1995). Recently, constituency development funds and social action funds, operating outside local government budgets, have become important funding sources for social and economic development projects at the local level in some countries, for instance, in Ghana, Kenya, Malawi, Tanzania, and Uganda (Baskin 2010).

\subsection{Who levies which taxes?}

There is no ideal assignment of revenue sources between central and lower levels of government. Still, a set of tax-assignment rules has been developed in traditional fiscal federalism theory (Oates 2005, 1972; Musgrave 2000; Bird 2010). These principles relate to the respective responsibilities of central and lower tiers of government in macroeconomic stabilisation, income redistribution, and resource allocation (Boadway et al. 2000). Furthermore, in developing countries the administrative capabilities of local governments in revenue design (deciding on revenue bases and setting rates) must be taken into consideration (Bird 1990). In large and diverse countries it is also important to address the issue of revenue harmonisation between jurisdictions when assigning taxing powers.

The need for stabilisation of the fiscal system leads to central control over the revenue instruments that may substantially influence central budget deficits or inflation. Thus, taxes on international transactions (customs duties) and a considerable share of income and general sales taxes (such as VAT) should be assigned to central government. If there are wide disparities in income and wealth across regions, as there are in many African countries, then local taxing powers may exacerbate these differences. Hence, the distributive function of government is an argument for centralised, progressive, corporate income and wealth taxes. Since the central government can borrow money to make up for shortfalls, it can live with the more unstable revenue sources, such as customs duties and income taxes. Local governments, by contrast, require relatively stable sources of revenue. Thus, lower-level

In some countries, such as Kenya, the amount of the loan is restricted. In other countries, such as Malawi, debt service levels are taken into account (Yatta and Vaillancourt 2010). This implies that the supervisory authority cannot approve a loan beyond a given debt service threshold. In most countries, supervisory authorities use the criteria of a threshold of local government's own resources to ensure that they can pay back loans. Generally, such borrowing is heavily constrained and contributes limited financial resources to the local government level. 
governments should tax revenue bases with low mobility between jurisdictions. Property tax is therefore often called the ideal local tax (see section 3.1). Moreover, if properly designed, user charges on trading services such as electricity, water, sanitation, and solid waste collection may be attractive local revenue instruments. The same applies to benefit taxes such as road and port tolls, and to various licences, which may also have regulatory functions (see sections 3.2 and 3.3).

While the general principles and theoretical discussions of revenue assignments summarised above are useful reference points, in practice country-specific factors play a crucial role when considering the best way to divide revenue responsibility between central and lower tiers of government (Bird 2010; Tanzi 2000). The case for centralisation is usually built around macroeconomic considerations and equalisation, and the case for local government on efficiency considerations and increased accountability. The optimal way to do things, however, depends on how the government weighs these considerations (Martinez-Vázques and Smoke 2010b; Boex 2009; Bahl and Wallich 1992). Furthermore, the capacity to administer revenue instruments is always an important constraint on the assignment of taxing powers to lower levels of government in developing countries. Last, but not least, local revenue sources must be politically acceptable (Bahl et al. 2003: 75). As a rule of thumb, less visible revenue instruments tend to be more acceptable to taxpayers.

Such assessments of tax assignment almost always favour central over subnational taxation. Although the literature generally emphasises that each level of government should be assigned taxes that are as closely related as possible to the benefits derived from spending them, it often also notes that 'if fiscal decentralisation is to be a reality, subnational governments must control their own sources of revenue' (Martinez-Vazquez et al. 2006: 21). However, as argued by Bird (2010: 5), it is not easy to satisfy both of these conditions: 'the standard model of tax assignment in a multi-tier governmental structure essentially assigns no productive taxes to subnational governments'. Local governments are often left with little but property tax, business licences, user charges and market fees, although, as discussed in section 3 , a wide range of low revenue-producing instruments is often in place.

\subsection{Transfers from central government}

Almost without exception, governments across the world assign more expenditure functions to local authorities than can be financed from their own revenue sources. This is also the case across anglophone Africa. The result of this mismatch of functions and finances usually referred to as vertical imbalances - is that local governments are generally dependent on transfers from higher levels of government (Bird 2010; Boadway and Shah 2009; Boex and Martinez-Vazquez 2006; Bird and Smart 2002). In addition, differences in local revenue bases and administrative capacities may create problems of equalisation (horizontal imbalance) between local government authorities, in particular between rural and urban areas. The presence of such imbalances means that one cannot design an appropriate system of local government taxation without simultaneously designing an appropriate system of intergovernmental transfers (Bird 2010: 1).

There are a number of methods to close the fiscal imbalances of subnational governments, some of which also reduce imbalances between jurisdictions (Ahmad 1997: 6). In practice, transfers may be in the form of surcharges or revenue sharing, whereby a local government receives a share of the revenue from specific taxes collected from within its jurisdiction by the central government (McLure 1999: 12). The main mechanism for intergovernmental transfers in anglophone Africa, however, is conditional and/or unconditional grants from central to local governments (Box 1). ${ }^{4}$ There are normally four such funding flows (Fjeldstad et al. 2010a):

$4 \quad$ See Ahmad (1997) for a more detailed discussion of intergovernmental fiscal transfers. Ajam (2001) provides a 
- Recurrent block grants: personal emoluments (PE) component

- Recurrent block grants: other charges (OC) component

- Recurrent subventions and basket funds

- Development (investment) grants and development funds

Of these, the recurrent block grant system generally provides the major funding for LGAs. In Tanzania, for instance, it supplied 65 per cent of all local government funds in fiscal year 2006/07, mainly from the PE component; the OC component accounted for less than 25 per cent of the recurrent block grant allocations.

\section{Box 1: Intergovernmental transfers in South Africa}

The equitable division of revenue raised nationally among the national, provincial and local spheres of government is a principle laid down in the South African Constitution. Intergovernmental transfers are therefore an important instrument within the South African fiscal system. The national revenue, less a contingency reserve and interest payments on state debts, is divided between the three spheres of government (vertical division).

Vertical transfers from the national sphere are mainly carried out via two instruments: unconditional shares and conditional grants. The Division of Revenue Act annually allocates national revenue to the different levels of government (including projections concerning the following two years to assure a certain degree of stability).

The decision on the allocation is based on previous consultations with provincial governments and organised local government as well as on the recommendations of the Financial and Fiscal Commission (www.ffc.co.za). A baseline allocation, reflecting the three year allocations from the last budget, is used as a starting point for consultations.

The Constitution provides that a nonpartisan Financial and Fiscal Commission (FFC) should advise parliament and subnational governments on a variety of issues in intergovernmental fiscal relations. These include taxing powers, the allocation of revenue between tiers of government, the grants system and borrowing powers.

Source: Chitembo (2009) based on Derichs and Einfeldt (2006)

Several countries have adopted a formula-based recurrent grant system to determine block grant ceilings for priority sectors, including primary education, health care, rural water supply, agricultural extension services and local road maintenance (Yatta and Vaillancourt 2010). The formula-based system designed for allocating grants to LGAs usually has the following factors: (i) size of population; (ii) number of school aged children; (iii) poverty count; (iv) infant mortality rate; and (v) distance from council headquarters to service outlets as proxy for land area. In Uganda, for instance, the Constitution establishes a formula for determining the minimum unconditional grant paid to local governments to run decentralised services (see Box 2). Besides the unconditional grant, local governments receive conditional and equalisation grants (Mugabi 2004: 3; Steffensen and Tidemand 2004). 


\section{Box 2: Unconditional grants to local governments in Ghana and Uganda}

Ghana uses a system where no less than 5 per cent of the total revenue collected by the central government is allocated to a 'Common Fund' for the disposal of subnational governments.

In Uganda, unconditional grants are determined annually with reference to the reassignment of tasks between the national and subnational governments. According to the Ugandan Constitution, the total amount is calculated using a formula that includes the unconditional grant of the previous year, corrected by the increase in the general price level, plus the net change in the budgeted costs of running newly devolved or subtracted services. Thus, the Ugandan formula takes into account the actual devolution of functions and its budgetary implications.

Source: Brosio (2000) and Mugabi (2004).

The level of intergovernmental transfers varies widely between countries and also between rural and urban councils within individual countries in East and Southern Africa (Chitembo 2009). Figure 1 illustrates the share of total local government revenue that stems from central government grants. In Botswana, for instance, rural councils receive 92 per cent of their total revenue from the central level, compared to 62 per cent for urban areas. In Uganda, local governments are heavily dependent on transfers from the central government (on average, 88 per cent of total revenue in 2007), while local governments in South Africa, on average, generate the bulk of the revenue from 'own' sources (89 per cent in 2007).

Figure 1: Intergovernmental transfers as percentage of total local revenue in some East and Southern African countries (2007)

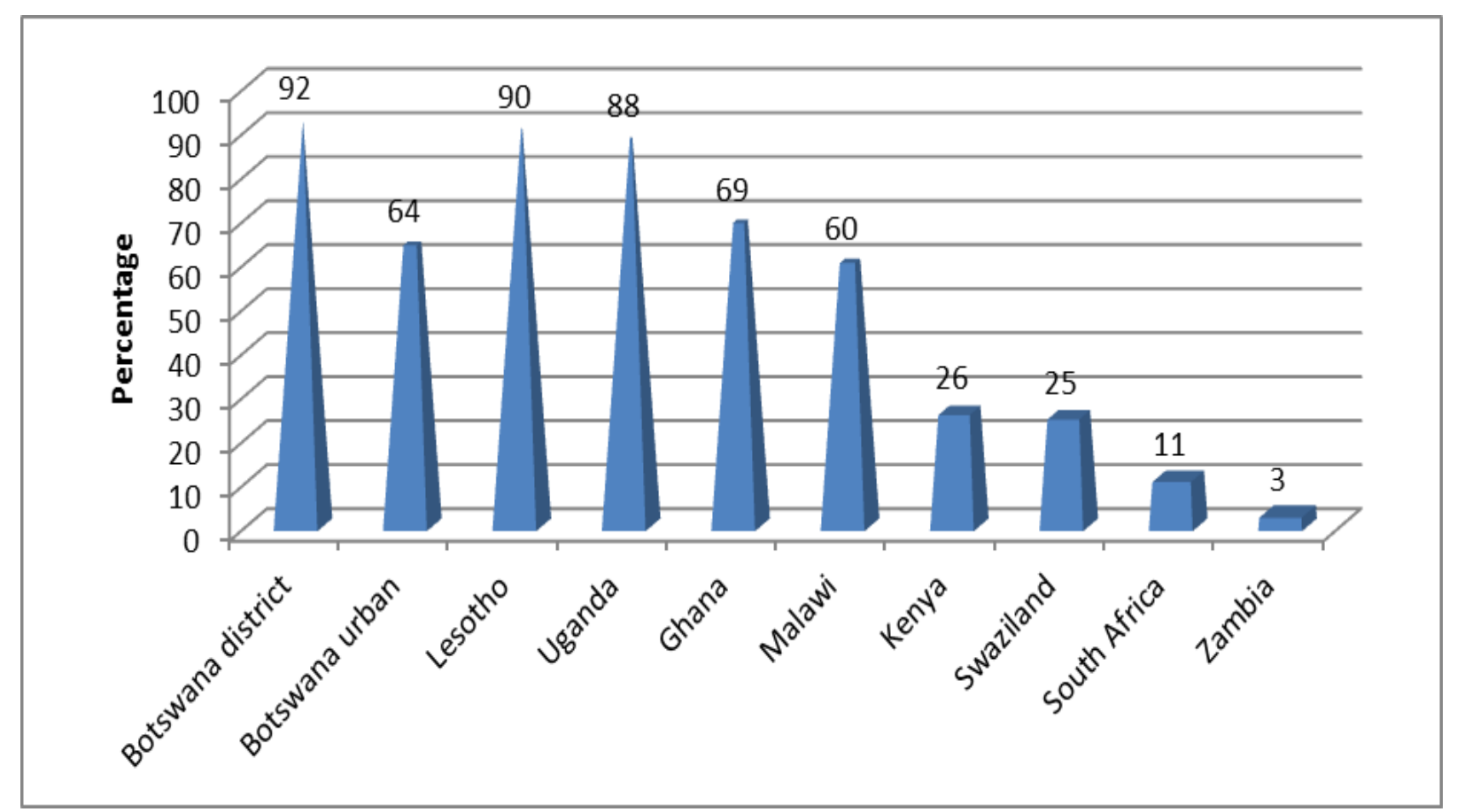

Source: Adapted from Chitembo (2009:11) citing Commonwealth Handbook 2007. 
Transfers and grants also constitute the biggest share of total receipts to local councils in anglophone West Africa. According to Jibao (2009: 43), local councils in Nigeria received on average almost 78 per cent of their revenue from transfers, in Sierra Leone 74 per cent, in Ghana 69 per cent, and in The Gambia 65 per cent. In Liberia revenue collection is centralised, and local councils rely totally on transfers from central government.

In the process of fiscal decentralisation, it is important to be aware of the risks for macroeconomic management and fiscal discipline. Substantial devolution of revenue and spending responsibilities to subnational jurisdictions can affect the central government's ability to carry out stabilisation and macroeconomic adjustment through the budget. The destabilising potential of subnational governments is greatest when they face no hard budget constraints (Bird 2010; World Bank 2000; Ter-Minassian 1999). Expectation of a bail-out when in financial trouble weakens the incentive to economise on costs, and may generate resource waste and rigidity within local authorities. These inefficiencies, in turn, may spill over into macroeconomic imbalances. In particular, concern for macroeconomic imbalance lies behind the common recommendation that strict limits should be imposed on the borrowing ability of subnational jurisdictions (Bird and Vaillancourt 1998). It is feared that subnational governments that are highly dependent on national transfers may increase their current expenditure above their capacity to fund it out of current revenue and then close the gap through borrowing. In Kenya the national government has made local government access to the Local Authorities Transfer Fund (LATF) conditional on progressive debt reduction (Yatta and Vaillancourt 2010: 44). ${ }^{5}$

A common pattern is that this dependency on central government transfers affects the local councils' ability to implement their development plans. The transfers are often highly volatile and delayed. In Tanzania, for instance, the national guidelines and budget ceilings developed by the Ministry of Finance, including information on grants, are often not received by the local government authorities until very late in the budgeting process (Fjeldstad et al $2010 b)$. Consequently, to initiate the planning process, some LGAs use indicative budget figures from the previous fiscal year. Jibao (2009) reports that there are cases when District Assemblies in Ghana receive their first quarter allocation of the Common Fund in the third or fourth quarter of the year, with the other three quarters overlapping into the following fiscal year and so on.

Perverse incentives, such as offering equal lump sum transfers to all local governments regardless of size, can lead to increased jurisdictional fragmentation. In Uganda, for instance, new local governments are constantly being created. This contributes to diluting the capacity of local governments in general (Martinez-Vázques and Smoke 2010b: 340).

However, a major challenge in many anglophone African countries is the implementation of a stable and transparent system of transfers, geared to filling gaps between the assigned spending and revenue-raising responsibilities of lower-level governments (Boadway and Shah 2009; Ter-Minassian 1999). The definition of such a system is far from easy, especially given the need to preserve adequate incentives for tax effort and cost effectiveness by the subnational governments. 


\section{Features of local government tax systems}

Many local tax systems in anglophone Africa are characterised by high levels of arbitrariness, coercion and corruption (Bahiigwa et al. 2004; Fjeldstad and Therkildsen 2008; Juul 2006; Prichard 2010; Pimhidzai and Fox 2011). A widely-found feature is the huge number of revenue instruments used by local authorities (Brosio 2000; Fjeldstad and Semboja 2000). Local governments seem to raise whatever taxes, fees, and charges they can, often without worrying excessively about the economic distortions and distribution effects that these instruments may create.

A complicated and non-transparent local government revenue system is costly to administer and can lead to corruption and mismanagement (Bardhan and Mookherjee 2002). Moreover, many local taxes distort resource allocation decisions, and inhibit the start-up of new enterprises and the achievement of economic growth (Bahiigwa et al. 2004; Devas and Kelly 2001; Sander 2003). These effects occur when effective rates vary greatly between different goods that are traded, or when licence fees are set too high for start-up small-scale enterprises to survive. In a study of small and medium sized enterprises in Zambia, Misch et al (2011) found that the effective tax burden varies substantially between firms. Enterprises face a range of different taxes, fees and licences, and the types of taxes that firms are subject to differ - not only between sectors, but also between firms within the same sector. The type of fees and levies differs substantially, even among businesses in the same municipality.

In addition, the levels and types of local revenue instruments by themselves can result in the tax burden falling more on the poor than on the relatively better-off in local communities. A recent study from Uganda shows that small, informal non-farm enterprises pay local taxes in a regressive way (Pimhidzai and Fox 2011). While the majority of the micro enterprises in the Ugandan sample were poor enough to be exempted from national business taxes (i.e. the small business tax and VAT), they ended up paying a large share of their profits to local authorities - with the poorest paying the highest share of profits. This is mainly due to the basic design of the local revenue system and the way revenues are collected. Thus, a topdown drive towards more taxation of this sector could be counterproductive, and would increase the vulnerability of these informal enterprises.

Consultation and cooperation between the central government revenue administration and local government authorities are generally limited. In Ghana, for example, national tax officials report that local tax officials sometimes urge citizens to pay local taxes instead of national taxes (Prichard 2010). Meanwhile, local officials complain that the national government has monopolised virtually all the available tax bases, and offers little if any administrative support. This lack of coordination has allowed a high degree of arbitrariness and abuse to emerge in local tax systems, while little attention is paid to economic efficiency. Due to lack of capacity and poor coordination between the central and local government, only limited questions are raised at the central level on local government's tax proposals. The local revenue systems have often developed without much interference from the centre. Furthermore, lack of coordination between the central and local levels has led to duplication of taxes, and inconsistencies between taxes imposed by local authorities (e.g. high taxes on export crops) and the national government's policy to encourage export production.

Firms often have to negotiate and provide similar information on their operations to several government bodies, imposing high compliance costs on the private sector (Fjeldstad and Heggstad 2011). For instance, in Tanzania the City Service Levy, a major local revenue source in urban councils, is levied as a fixed percentage of the firm's turnover ( 0.1 per cent of turnover for the bank/financial sector, and 0.3 per cent for other sectors). It requires the same data for tax assessment that the central government tax administration requires for corporate 
income tax. The duplication of databases also implies higher administrative costs on the public sector.

A recent study of the tax systems in Mozambique, Tanzania and Zambia finds that local taxation is still a major constraint on the commercialisation of smallholder agriculture and formalisation of small and micro enterprises (ibid.). Specifically, multiple taxes (including fees and charges) make it difficult to enter new businesses and markets. Levies are perceived as exorbitant, often charged up-front irrespective of the size and type of business (Misch et al. 2011). New local taxes, fees and charges have been introduced, replacing taxes abolished by the government in recent years. This contributes to undermining the legitimacy of the local tax system, encourages tax evasion and delays the formalisation of micro and small-scale enterprises. Furthermore, it undermines initiatives encouraging compliance such as community outreach and taxpayer education.

Arbitrariness, corruption and regressiveness have made local taxes generally unpopular and ineffective (Prichard 2010). Despite many comprehensive central government tax reforms during the last two decades, until recently local government revenue systems in sub-Saharan Africa have remained largely unchanged, with a few exceptions. For instance, in 2003/04 Tanzania conducted a comprehensive reform of its local revenue system (see Box 3 ). The main elements of this reform were: (i) abolishing unsatisfactory local revenue instruments (including the poll tax), which were costly to collect from administrative and political perspectives; and (ii) improving the remaining revenue bases by simplifying rate structures and collection procedures. The Tanzanian reform demonstrates that radical changes of the local revenue system are possible. The longer-term impact of this reform on local government revenues, however, has been reduced fiscal autonomy and increased dependency on central government transfers (Fjeldstad et al 2010a). ${ }^{6}$ Uganda abolished its graduated personal tax in 2005 in response to its growing unpopularity and politicisation, with a similar impact on local revenues (Fjeldstad and Therkildsen 2008).

Generally, a fundamental requirement when redesigning local revenue systems is greater emphasis on the cost-effectiveness of revenue collection, taking into account not only the direct costs of revenue administration, but also the overall costs to the economy, including compliance costs for taxpayers. In addition, losses through corruption and evasion need to be reduced. Clearly, improved revenue administration cannot compensate for bad revenue design. Thus, reforming the revenue structure should precede the reform of revenue administration, since there is not much merit in making a bad revenue system work a bit better.

Nevertheless, surveys in both Tanzania and Uganda indicate that citizens have a general appreciation of the need for taxation to support local service provision, but choose noncompliance due to lack of confidence in local government (Bahiigwa et al. 2004; Fjeldstad et al. 2009a). Studies from Tanzania suggest that people's views on local taxation may change over time, which has implications for policy design. Based on survey data from 2003 and 2006, Fjeldstad et al (2009a) found that people were much more positive towards the tax system in 2006 compared to three years earlier. This, the authors suggest, was partly due to improvements in service delivery, particularly education, health, and law and order, and

For instance, a sample of rural councils in Tanzania generated on average only $2 \%$ of total revenues in 2005 (after the reform) from own sources, compared to $13 \%$ in 2002 (before the reform). This drop in own revenue generation is partly due to the abolition of many local revenue sources in 2003 , including the head tax 'development levy', and partly due to the sharp increase in central government grants to local government authorities. The larger llala Municipal Council and Mwanza City Council also experienced a drop in their own contributions to total revenues, partly due to the abolition of business licences in 2004. Ilala MC generated 45\% of its total revenues in 2005 compared to $64 \%$ in 2002, while Mwanza CC saw a reduction from 48\% in 2002 to $22 \%$ in 2005 (Fjeldstad et al 2010a). Business licences were reintroduced in 2011. 
partly due to reforms which led to less oppressive revenue collection. Corruption, however, was perceived by citizens to be a major problem in both surveys, with implications for their trust in government and government officials and, thus, their willingness to pay taxes and fees. There was also an increasing demand by citizens for more information on revenue collected and how the revenue was spent.

\section{Box 3: Reforming the local government revenue system in Tanzania}

Until mid-2003, local authorities in Tanzania often had more than 70 different taxes, fees, and charges. In addition, there were many sub-groups of specific revenue instruments. There were also large variations in the rates imposed by councils on similar revenue bases, which led to smuggling of tradable goods across council borders within the country.

In June 2003, a comprehensive reform of the local government revenue system was carried out. A large number of so-called nuisance taxes, which were costly to administrate and generated limited revenue, were rationalised. In June 2004 local business licences were abolished, based on the argument that they provided disincentives for the development of local enterprises. The Tanzanian reform demonstrates that radical changes of the local revenue system are possible. The longer-term impact of this reform on local government revenues, however, has been reduced fiscal autonomy and increased dependency on central government transfers.

Work initiated by the ministry responsible for local authorities focuses on reforming the current local revenue system and to identify new revenue options. Among the proposals discussed are reforms of the property tax system and introduction of a unified business tax. As part of this work, business licences were reintroduced in July 2011 (URT 2011: 41). Moreover, many councils have started to explore methods to reduce the financial gap caused by the rationalisation by:

1. outsourcing revenue collection to private collectors to increase revenue from existing sources;

2. reducing costs (for example, by limiting the number of meetings and workshops and by retrenching surplus staff); and

3. imposing more cost-effective spending (for example, on electricity and stationery).

Current attempts for economic diversification may also help to expand the local revenue base in the longer term. Furthermore, co-production of services by councils and local communities is on the rise. For instance, an increasing number of primary schools are maintained and expanded via self-help schemes combined with technical support from the local government authorities.

Source: Fjeldstad et al. (2004).

\section{Local government 'own revenue' instruments}

As noted above, the local government own revenue systems across anglophone Africa are often characterised by a huge number of revenue instruments. However, the main sources of own revenue are usually property rates in urban councils, business licences, market fees and 
various user charges, often surcharges for services provided by or on behalf of the local government authority. Nevertheless, the experience of a number of African countries shows that these revenue instruments have serious shortfalls. For instance, property taxes can be very costly to administer (Brosio 2000: 20; McCluskey and Franzsen 2005), and the enforcement of user fees has resulted in widespread resistance to paying from the poorer segments of the urban population in some countries (Fjeldstad 2004; Fjeldstad et al 2005). Moreover, complex business licensing systems have proved to be major impediments to the start-up and expansion of especially micro and small enterprises (Devas and Kelly 2001; Sander 2003; Pimhidzai and Fox 2011). However, experience from other regions shows that when well administered, these revenue instruments can provide substantial and reliable revenues for urban municipalities.

\subsection{Property tax}

Textbooks on revenue assignment between various levels of government generally argue that few fiscally significant taxes are more appropriate to local administration than property tax. This is due to the fact that real estate is visible, immobile, and a clear indicator of one form of wealth. Hence, in principle, property tax is difficult to avoid, and, if well administered, it can represent a non-distortional and highly efficient fiscal tool.

Property tax as an annual tax on real property is levied in all anglophone countries in Africa except in the Seychelles (McCluskey and Franzsen 2005). It is usually a local government tax, levied mainly in urban areas (Table 1). The property tax is a national tax only in Liberia. Rural properties are often not taxed, although property taxation is being extended to rural properties in South Africa under the terms of the Local Government: Municipal Property Rates Act 6 of 2004 (Franzsen 2007: 12). Namibia introduced a land tax on commercial farmers in 2004 in order to fund a land reform programme.

Table 1: Types of property tax in anglophone Africa

\begin{tabular}{|l|l|l|l|l|}
\hline & $\begin{array}{l}\text { Property } \\
\text { transfer tax }\end{array}$ & $\begin{array}{l}\text { Urban } \\
\text { property tax }\end{array}$ & $\begin{array}{l}\text { Value added } \\
\text { tax }\end{array}$ & $\begin{array}{l}\text { Rural property } \\
\text { tax }\end{array}$ \\
\hline Namibia & Yes & Yes & Yes & Yes \\
\hline South Africa & Yes & Yes & Yes & Yes \\
\hline Kenya & Yes & Yes & Yes & In principle \\
\hline Mauritius & Yes & Yes & Yes & \\
\hline Nigeria & Yes & Yes & Yes & \\
\hline Botswana & Yes & Yes & Yes & \\
\hline Ghana & Yes & Yes & Yes & \\
\hline Lesotho & Yes & Yes & Yes & \\
\hline Malawi & Yes & Yes & Yes & \\
\hline Sierra Leone & Yes & Yes & Yes & \\
\hline Tanzania & Yes & Yes & Yes & \\
\hline Uganda & Yes & Yes & Yes & \\
\hline
\end{tabular}




\begin{tabular}{|l|l|l|l|l|}
\hline Zambia & Yes & Yes & Yes & \\
\hline The Gambia & Yes & Yes & & \\
\hline Swaziland & Yes & Yes & & \\
\hline Seychelles & Yes & & & \\
\hline
\end{tabular}

Note: 'Yes' indicates that property taxes are in place. Empty boxes indicate that the tax is not levied in the respective country.

Source: Franzsen (2007:10).

Property tax reforms have taken place in most anglophone African countries for more than a decade. Figure 2 gives an overview of when property tax reforms were initiated in selected countries since 1997.

Figure 2: Property tax reform in a selection of anglophone African countries

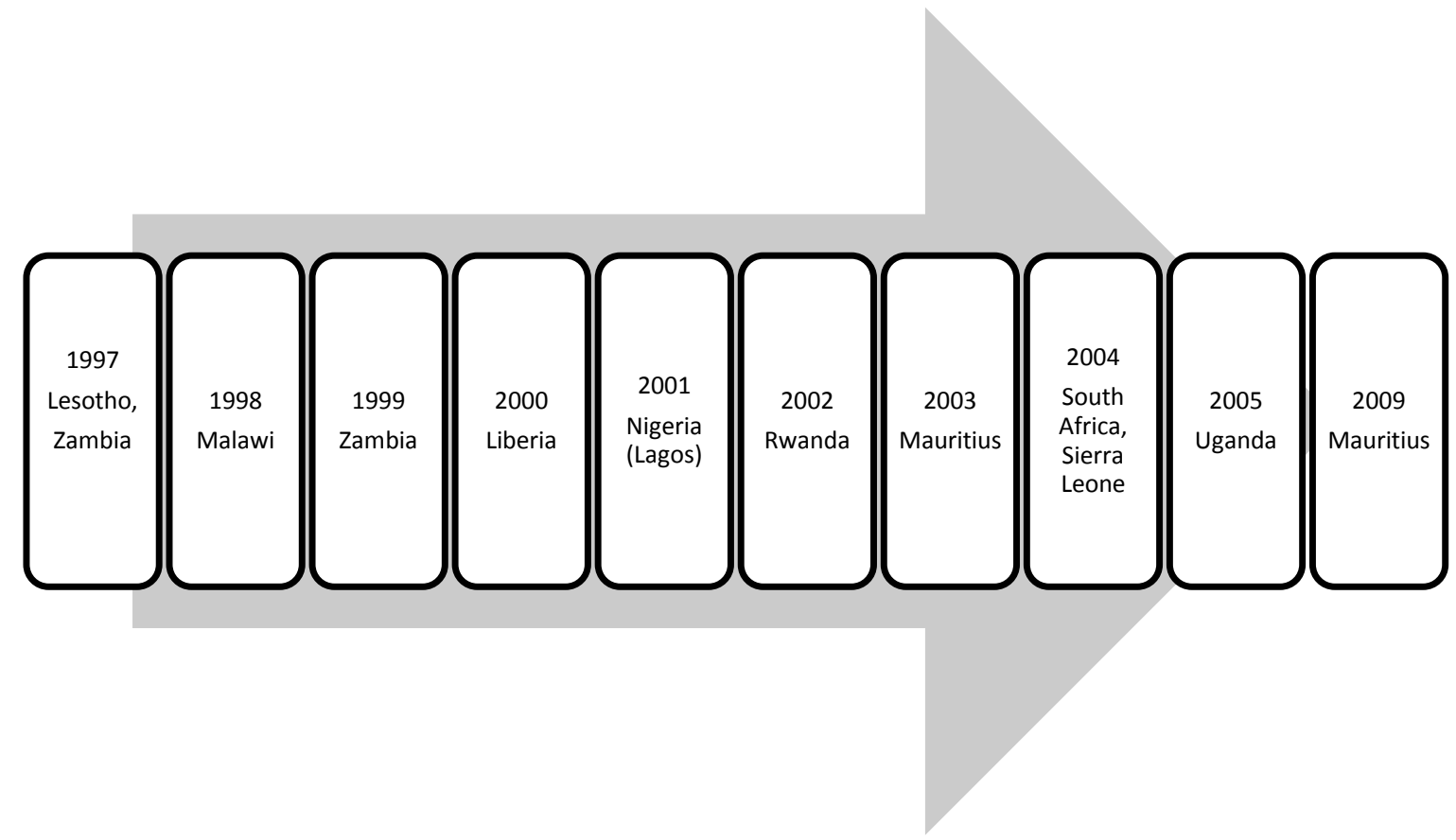

Source: Franzsen and Youngman (2009:10).

Property tax revenue accounts for less than 0.5 per cent of GDP in many African countries. In the 1990s, property taxes accounted for 40 per cent of all subnational taxes in developing countries (Bird and Slack 2002: 6), but less in most African countries. For instance, property tax accounted for 10-30 per cent of own revenue in urban councils in Tanzania (Fjeldstad et al. 2004), and around 20 per cent in metropolitan councils in South Africa (Bahl and Smoke 2003). In Ghana property tax accounts for about 14 per cent of the total revenue of local assemblies, an average of 6.1 per cent in local councils in Sierra Leone, and less than 10 per cent in The Gambia (average for the period 2006-2008). In Liberia, where local councils are not allowed to collect revenue, property tax accounts for about 1 per cent of total revenue of the central government (Jibao 2009).

Why is property tax not more heavily exploited as a local revenue source in Africa? There are a number of constraints that can explain why (Bell and Bowman, 2006): (a) with the 
exception of Botswana, Namibia and South Africa, property markets are not well developed; (b) property registers and valuation rolls are often outdated or not in place; (c) administrative capacity and equipment are often limited; (d) the tax base is generally narrowed by extensive legal exemptions; and (e) lack of political support to enforce the property tax and political interference in revenue collection. Mikesell (2002: 22) argues that the reasons are considerably more political than economic (see Box 4). First, those who are more familiar with income and consumption taxes than with property taxation exaggerate the difficulty and cost of administering an equitable property tax. Second, in many countries the property tax has powerful political enemies. The tax strikes rich people quite directly, and the levy itself is visible. People with considerable wealth in property usually have considerable political power, and use that power to thwart taxes that aim directly at their holdings. As Burgess and Stern (1993: 802) suggest, low utilisation of property and land taxation 'reflects the success of the resistance of the rich and powerful to measures which harm their interests'. The result is that taxes are paid on a base that often bears little resemblance to the true level of property values (Franzsen, 2007: 8-9).

\section{Box 4: Property taxation and political engagement in Kenya}

During the 1980s members of the Karen and Langata District Association (KLDA) in Kenya became increasingly frustrated with high municipal property taxes and the absence of effective service provision and fiscal transparency. In response the KLDA went to court to demand that the city council improved transparency before collecting additional taxes. The KLDA won the case, though the city council refused to comply. Consequently, property taxes were placed by KLDA members into an untouched bank account for over a decade.

In recent years the KLDA has offered to release the funds if the city council will grant them greater control over local planning and public spending. Although the lack of progress is discouraging, there is some hope that the initial tax conflict may lead to a more constructive partnership between the district association and the government.

Source: Prichard (2010: 40).

When local governments administer the tax, they are responsible for maintaining property and ownership records, determining taxable property values, calculating and distributing property tax bills, managing receipt of payments, and applying tax enforcement against nonpayers (Mikesell 2002: 22). In other cases, local governments have a say in the tax rate, but the national revenue authority administers the tax. In some countries, for instance in Malawi, property valuation is done by the central government, while local authorities set rates and handle collection (ibid: 28). West African francophone countries in general rely on the traditional French model, in which the property tax is designed and administered by the central government. Anglophone African countries, with the exception of Liberia, rely on local administration (Brosio 2000; Jibao 2009). This is usually recommended in the literature, which stresses that taxes should be administered by the government that is entitled to their revenue. However, mixed results prevail in both anglophone and francophone Africa.

The most common form of property tax in anglophone countries is on property value, even though there may be little capacity to implement accurate valuation practices. Availability of relevant property registers and data is generally limited, except in South Africa. Valuation rolls, if they exist, are normally out of date. Lack of qualified valuers to prepare or maintain valuation rolls is also a challenge, again with South Africa as an exception (Franzsen 2007). Efforts to address these shortfalls are reflected in a noticeable move away from relying on central government valuation offices to prepare valuation rolls (e.g. in Lesotho, Malawi, 
Mauritius, Swaziland, South Africa, Uganda, and Zambia). Some countries, for instance South Africa and Uganda, have introduced 'mass valuation' as an alternative to discrete valuations of individual properties, or are considering doing this (e.g. Kenya). However, external quality control with regard to valuation rolls is practically non-existent. Only the new South African legislation provides for ministerial oversight regarding the effectiveness, consistency, uniformity, and application of municipal valuations.

Most countries apply different tax rates to different types of property (Franzsen 2007). Rates are generally determined annually (e.g. Botswana, Namibia, South Africa, and Swaziland). In some instances they are set by central government or municipal by-laws for a fixed or indefinite period, so rates may remain static for years (e.g. Ghana and Tanzania). Where differential rates apply, the tax rates for residential properties tend to be significantly lower than the rates for commercial, industrial, and government properties, when these are taxable (e.g. Lesotho, Swaziland and Zambia).

There is generally a distinction between imposing tax on land or buildings. Since land in many African countries is owned by the state, often only buildings are included in the property tax base. This applies to Tanzania, Ghana, Mozambique and Sierra Leone. Kenya is the only African country with a land value tax, while South Africa has a uniform, capital value tax. Nigeria is unique in having formally delegated the authority for property tax legislation to the 36 state governments, leaving the various areas in Nigeria with different approaches to estimating property tax (Franzsen and Youngman, 2009: 12). The property tax base in some countries in anglophone West Africa is summarised in Box 5.

\section{Box 5: The property tax base in anglophone West Africa}

In Sierra Leone, property tax (known as City Rate in Freetown and Town Rate in other urban towns) is levied on buildings whether occupied or unoccupied. Although the tax base includes government buildings (whether owned or occupied), government has not been paying property tax over the years for buildings it owns. Ideally, councils agree not to levy tax on government owned buildings in return for councils not having to pay whatever they may owe to the central government.

In Ghana, property tax is levied on premises comprising buildings or structures or similar developments (Local Government Act 1993). Vacant lands do not attract tax. However, with effect from January 2008, different (flat) rates are assigned to undeveloped plots located in different areas in the Accra Metropolitan.

In The Gambia, property tax (known as Compound Rate) is levied on premises which include: any building together with all lands occupied therewith which is a distinct or separate holding or tenancy; any land whether developed or underdeveloped; or any wharf pier or ramp (Section 2, General Rate Act 1992). The rates are levied on the basis of an assessment in respect of the capital value of property in the rating areas.

Source: Jibao (2009).

In theory, assessment of property value and revenue collection are straightforward: conduct a cadastral survey that assesses the market or site value of each plot of land or property, and send a tax bill to each owner. In practice, however, cadastral surveys are expensive and time-consuming (Bahl et al. 2003: 79). The task is often beyond the financial and technical capability of many local governments (see Box 6). Tax offices in many sub-Saharan African countries, except in South Africa, are short on assessors, if they have any at all (FarvacqueVitkovic and Godin 1998). In Uganda, for instance, there were eleven certified land and property valuators responsible for valuing three million parcels in 2002 (McCluskey et al. 
2003). The corresponding figures for Tanzania were approximately 100 certified valuators and five million parcels. Thus, it is difficult to conduct and maintain assessments, which often are eroded by inflation. It is difficult to administer, particularly when property prices are changing rapidly. Accordingly, the property tax base is inelastic, despite growth in the physical size or value of property, because old valuations are not updated and new properties not identified. In most cases, the system has been inherited from the colonial era and is poorly suited to present conditions.

\section{Box 6: Deficient property tax administration in Kampala}

The seriously deficient administration of the property tax in Uganda exemplifies the difficulties this tax has in providing substantial revenues to local governments in Africa. Although any local authority has the legal right to levy property taxes, in practice only municipalities and town councils levy them. Undeveloped land is not taxed, which inhibits the efficient use thereof.

The property tax is based on seriously outdated valuations, which are very low, although the law requires that valuations be carried out every five years. Many valuable properties are not taxed at all, and many newly refurbished buildings have not been revalued. Systems of recording and valuing properties are seriously deficient. This is partly because the skilled technical staff needed to organise and supervise valuation work are in short supply.

The city of Kampala also shows a phenomenon that is taking place in many other metropolitan areas in Africa. Its urbanised area has expanded beyond its municipal boundaries, but neighbouring districts are either not allowed to levy property tax on residential properties, or abstain from doing so because they still have to provide basic urban services to these areas. Low revenue is also attributable to poor collection, huge delays in payments, or simply non-payment. Non-payment also derives from the high mobility of people, frequent property sales/exchanges, and the inadequate registration of titles.

Source: McCluskey et al. (2003).

Property registers and valuation rolls (cadastral systems) may work in areas with regular street patterns, named streets, and numbered houses. In the absence of street addresses, tax bills are not deliverable, and penalties are unenforceable. Although revenue collection may also prove to be problematic in areas where the property matrix is in place, the absence or scarcity of clear ownership titles is a serious challenge facing this form of taxation. Collection is often poor and many bills go unpaid because taxpayers are not identified, or they resist payment because their housing conditions are too poor or urban basic services are not provided to their areas. In principle, non-compliance of property tax can be enforced by confiscation and sale of the owner's personal effects in the building initially, and ultimately through the collateral of the real estate itself. However, experience shows that courts are often swamped by appeals from angry property owners and landowners (Skinner 1993: 364). Moreover, harsh enforcement mechanisms may result in intervention from politicians facing complaints from their constituents (Enemuo 2000: 193). Thus, high administrative and political costs are the crucial problems of property taxation.

Expert opinion diverges on how to improve property taxation in developing countries. ${ }^{7}$ Some blame the excessive centralisation of property tax policy, which prevents setting higher tax rates. Others blame what they consider the almost total anarchy deriving from local government freedom in this field. There is also dispute over tax administration. Certainly,

Dillinger (1991) provides an insightful summary of these challenges, which is still valid. 
property taxes have many attractions as local bases, but they also have obvious weaknesses that need to be taken into consideration before heavy reliance is placed on them. Often the capability and capacity of the municipality are inadequate to administrate the property tax at a low cost (McCluskey et al. 2003: 23). As noted above, these administrative weaknesses are manifested in problems of valuation and arbitrariness in tax assessment and enforcement.

Foreign donors have funded many projects aiming to reform the property tax system and build local administrative capacity, with mixed results. However, if property tax is to play a greater role in municipal finances, the administrative and technical features of the system must not become obstacles. Hence, technical assistance should prioritise appropriate training of property valuators and upgrading relevant skills of municipal staff. Current legislation is often a major obstacle in many countries (for example, in Tanzania and Uganda), and needs to be revised (McCluskey et al. 2003). The Municipal Property Rates Act of 2004 in South Africa shows that it is feasible to address some of these problems by stipulating nationally uniform mechanisms of assessment, and a monitoring process to ensure assessment quality.

Clearly, property tax has to be simplified to adapt it to the reality of many African countries. Ambitious cadastral projects were undertaken in the 1980s, but many of them failed or were abandoned halfway, as in Cameroon, Mali, and Senegal. Today, advisors therefore recommend the use of very simple parametric methods for the evaluation of property values. Parameters could include the number of rooms, the quality of the building materials, and the area of the city where the building is located. Such parameters are transparent and, in general, easy to apply. Such methods have been used in a number of countries (also in Western Europe) with satisfactory results. Administration could be left local, but the legal framework should be centrally provided. Nevertheless, research undertaken by the Africa Tax Institute ${ }^{8}$ argues that many African countries face major challenges if the property tax is to provide a reliable and adequate source of revenue for municipalities. In some countries even the rationality and administrative feasibility of property tax policies and current legislation must be questioned.

\subsection{Business licences}

In anglophone Africa, the standard mechanism for mobilising revenues from businesses has been through licensing. Although the original intent was regulatory, in most places local business licensing has increasingly become simply a revenue source. Typically, business licences generate between 5 and 30 per cent of local government own revenue in urban councils. In many countries, however, the system has been quite unsatisfactory. It has often been quite inequitable, imposed huge costs on business, and generated relatively little money. In Uganda, for instance, a common complaint from small and medium-sized enterprises has been that 'they do not know what to pay, where and to whom'. The regulatory aspects of the licence system have been largely abandoned. In addition, poor policy design and weak administration mean that licence coverage, assessment, collection, and enforcement rates are low, leading to poor revenue generation.

Local business taxes are generally levied in one of two ways (Devas and Kelly 2001: 384): either as a fixed amount, which usually varies by type, size, or location of the business; or as a percentage of turnover or profits. Assessing turnover or profitability, however, is difficult both in relation to small businesses, which often do not maintain proper records, and to large businesses with multiple premises across various jurisdictions. Thus, local business taxes often use proxies for turnover or profitability, such as the size of premises, type of business, number of employees, installed electricity power, etc. 
Obtaining a licence typically involves multiple visits to various offices, sometimes over several days, with associated travel costs. Failure to provide the correct licence receipts may result in closure of the premises. Consequently, the system is often riddled with rent seeking and corruption. Poor administration often means that many businesses are not included in the licence system due to lack of proper business registers (Arajou-Bonjean and Chambas 2003; Brun et al 2012). Weak financial management often means that collection and enforcement provisions are rarely enforced. This erodes the tax base and introduces inequities into the system. Thus, many existing business licence systems across Africa contain serious defects. These include (Devas and Kelly 2001: 385):

- high compliance costs to businesses, due to multiple licensing and complex procedures;

- tariff structures that are complicated and do not reflect ability to pay;

- a process loaded with ineffective regulatory requirements, which provide opportunities for rent seeking;

- poor administration and evasion, which reduce the tax base and generate inequities; and

- a revenue source that generates relatively little income for local governments.

Several African countries have reformed (Kenya, Tanzania and Uganda), or are in the process of reforming, their local business licence systems, to make them simpler, more transparent, and effective (Sander 2003; URT 2005; USAID 2005). ${ }^{9}$ The main objectives of these reforms are to enable local authorities to collect significantly more revenue, and to reduce the compliance burden on businesses. In the late 1990s, Kenya pioneered a single business permit (SBP) system, which has since become a model for other countries in the region (see Box 7).

The Kenyan SBP system was introduced on an optional basis in 1999, with all local authorities being required to adopt it from January 2000. According to Devas and Kelly (2001: 387), the initial reports were positive. However, a major problem experienced during implementation was the lack of effective dialogue and communication with the local business community in the early stages, leading to misunderstandings and some initial resistance to the reform. Moreover, some local authorities chose inappropriate tariff sets - usually too high. This led to tax resistance from local traders. There were also cases of business misclassification (over-assessment), leading to calls for improved administration, transparency, and accountability (Devas and Kelly 2001). On the positive side, however, most local governments experienced substantial increases in revenue - some councils more than doubled their revenue from this source in one year. In some cases, this was due to improvements in coverage of the revenue base, but in most cases the increase was due to choosing higher tariff sets (ibid: 388). 


\section{Box 7: The Single Business Permit (SBP) in Kenya}

The Kenyan business licence reform has the following components:

1. Local business licensing is decoupled from regulatory requirements, since these are usually ineffective and create opportunities for rent seeking.

2. All economic activities within the local jurisdiction are, in principle, included in the base. The law was amended to broaden the base to include all businesses and trades, including professionals such as lawyers, doctors, and private consultants. This aimed to widen the revenue base and to improve equity, while at the same time minimising the economic distortions of the licence system. To avoid double taxation, the central government abolished its registration fees on professionals.

3. Businesses are only required to have one business permit per premise regardless of the range of activities carried out there, hence the name Single Business Permit (SBP).

4. Local authorities are required to establish 'one-stop-shops', at which permits will be issued on the spot in exchange for the appropriate fee. The philosophy is a more customer-oriented approach to business licensing.

5. A standardised rate structure is established. Businesses are classified into eight sectors, which are subdivided into broad categories reflecting the scale of profitability of the business. These size categories are based on easily identifiable and objective criteria. The system is based on self-declaration, but with the opportunity for official checking.

6. The tariff structure is designed to be progressive, with smaller businesses paying less than larger ones. The system provides a standard tariff structure for all local authorities, but still allows local government discretion over the actual tariff rates.

7. Measures are taken to improve the local administration of the system. This includes the design of simplified SBP registration forms. Training is provided to encourage local authorities to work with the local business community in choosing the SBP tariff schedule.

Source: Devas and Kelly (2001).

In both Kenya and Uganda, the time required to obtain business permits has been substantially reduced due to the introduction of one-stop-shops (Box 8). This has cut the compliance costs of enterprises, though not necessarily the total costs since the tariffs have been raised. In general, however, collection performance remains a problem and there is a need for improved financial management. However, the early evidence is fairly positive (Gamser 2003). The new system seems to enable local authorities to enhance revenues. At the same time, compliance costs on businesses are lowered and the opportunities for rent seeking and corruption are reduced. 


\section{Box 8: Streamlining business registration in Entebbe municipality, Uganda}

Until recently, the business registration and licensing system in Uganda was very complicated and time-consuming. On average, it took 36 days to register a business. Hence, many small and micro enterprises avoided the registration process and remained informal.

A one-stop simplified business registration and licensing system was piloted in Entebbe in 2002-2003. The results of the pilot include:

- The licensing process became cheaper and shorter. Overall, the compliance costs for enterprises were reduced by $75 \%$ (for example, registration time was reduced to 30 minutes).

- Compliance levels for registration improved by $43 \%$.

- Total revenue collection increased by $40 \%$.

- Administrative costs for the council were reduced. Administrative savings were $25 \%$ in staff time and $10 \%$ in financial resources.

- There were reduced opportunities for bribery.

- Relations between local authority staff and businesses were improved.

Source: Sander (2003).

In francophone Africa, local governments levy a tax called the Patente, which was originally based on the French Taxe Professionelle (Devas and Kelly 2001). In Cote D'Ivoire, the Patente was the largest single local revenue source in the 1990s, financing about 17 per cent of the local government budget, and more in the commercial capital Abidjan. The calculation of this tax is quite complex, involving the value of the premises, number of employees, turnover, machinery employed, installed energy capacity, and other size proxies. Moreover, within this formula, rental value of premises is by far the largest factor, so the tax starts to resemble a property tax.

Atypical for anglophone Africa, urban councils in Tanzania levy a local business tax called the City Service Levy (CSL). The CSL is levied as a fixed percentage of the firm's turnover ( 0.1 per cent of turnover for the bank/financial sector, and 0.3 per cent for other sectors). It is a major local tax in municipalities. For instance, in Ilala Municipality, Dar es Salaam, the CSL generated in 2006/07 more than 47 per cent of the total revenues from the municipal's own sources (Fjeldstad et al 2010a). For the large VAT-registered taxpayers, CSL-billing is levied quarterly; it is paid annually for the majority of small taxpayers who are not registered for VAT (URT 2003: 34). The amount billed is in essence a provisional tax based on 30 per cent of the firm's presumed annual turnover. Monitoring the turnover of large numbers of small businesses, data collection and maintenance of tax registers have proved to be costly and time-consuming. Information sharing and professional working relations between the municipalities and relevant central government bodies for the purposes of the CSL are only utilised to a limited extent. Hence, on various occasions the issue has been raised whether CSL should be collected as part of Corporate Income Tax by the central government's tax agency, the Tanzania Revenue Authority (TRA). However, municipalities have expressed concern that if the City Service Levy were to be collected by the TRA, central government may too easily retain the revenue or merely seize taxing powers for this source of revenue (ibid: 35). 


\subsection{User fees - linking payment and service delivery}

Taxes are not the best mechanism for matching demand and supply of public services. Better links can be achieved through cost-recovery charging systems, which tie the amount paid directly to the amount consumed. By providing a more direct link between citizens' contributions and service delivery, such mechanisms may be more a effective way to recover the costs of service provision, and to promote efficiency in the consumption of the service. Hence, most observers argue that user fees should play a prominent role in local government finance (Bahl et al. 2003: 76; Bird 2001).

The main economic rationale for user charges is not to produce revenue, but to encourage the efficient use of resources within the public sector. When properly designed, user charges provide information to public sector suppliers on how much clients are willing to pay for particular services, and ensure that citizens value what the public sector supplies. Free or subsidised services may result in over-consumption of such services, and it may prove difficult to target the beneficiaries of free services (Box 9). Yet, experience from several countries, including Namibia and South Africa, show that user charges can impose a heavy burden on lower-income service users, and exclude the poorer segments of the urban population from the services (Fjeldstad et al 2005; McDonald and Pape 2002). Adjustments can, however, be made to offset such effects. For instance, user charges can reflect differences in ability to pay by incorporating sliding scales for the type of user or the amount of usage (Rondinelli et al. 1989: 71), although this will require adequate administrative capacity.

\section{Box 9: Free services to the poor in South Africa}

Improved service delivery to the poor is a priority for most African governments. In South Africa, for instance, the two pillars of this policy are to enable local governments to:

- make basic municipal services accessible to all citizens, and

- provide free basic services for poor citizens who cannot pay.

The challenge with respect to service delivery is to ensure that poor households are the primary beneficiaries of the free services policy and associated resources. Since July 2001, every municipality in South Africa is supposed to provide at least the minimum free 'lifeline' supply to households of 6,000 litres of water and $50 \mathrm{~kW}$ of electricity per month.

Some observers have raised concerns with the manner in which this lifeline policy has been designed and implemented. Firstly, it is argued that the quantity of free services provided is too small. Secondly, since households are not means tested to see if they qualify for the free services, some middle- and upper-income households are benefiting more than poor households. Finally, there is the problem of delivering free services across the country, particularly in rural areas. Therefore, many municipalities have developed indigent registers to ensure that free basic services are provided to the poor.

Source: Fjeldstad (2004).

User charges for trading services, including water, electricity, sewage, and solid waste removal, are major sources of revenue in urban municipalities in Southern Africa, especially in Namibia and South Africa (Fjeldstad et al. 2005; Bahl and Smoke 2003). In particular, service charges on water and electricity supply are important. This revenue is generated by a surcharge. This is either added to the cost of the utilities that the local authorities typically buy from the utility companies, or, if the authority itself produces the utility, added to the cost of producing it. 
According to Bahl et al. (2003: 77), around a quarter of the electricity-distributing authorities in South Africa raise substantial revenues from the surpluses earned from their sales. A large share of these revenues is used to cover the cost of providing the service. However, in some municipalities a substantial surplus is left for general local government purposes. Hence, the tax component of the user fee is hidden for ratepayers, and the true level of local government taxation is not transparent to citizens. This undermines the potential accountability capability of the local revenue system. Moreover, since the consumer price of the service (for example, electricity) is overstated by the amount of the implicit tax, this may have negative impacts on economic efficiency.

In Namibia, the majority of town councils are not determining their tariffs in accordance with an approved tariff policy of cost recovery (Fjeldstad et al 2005). Hence, several trading services, including water distribution, are operated with significant losses in a number of local authorities. This is also the situation for around a quarter of the municipalities in South Africa (Bahl and Smoke 2003). The situation is worsened by an increasing number of outstanding debtors in many local authorities - consumers who do not pay for basic services due to various reasons, including affordability.

Experience from South Africa and Namibia shows that there are a number of obvious constraints on user charges and other means of cost recovery. These arise from equity considerations (i.e. ability to pay), collection and billing methods (Box 10), the quality of the services provided, and persistent resistance to paying. These lessons show that dealing with the policy problem of revenue enhancement requires some understanding of the factors underlying the individual's decision of whether or not to pay service charges (and taxes).

\section{Box 10: Improving compliance through shared private water taps in Ondangwa, Namibia}

Residents in the poor informal settlements in Ondangwa Town Council, Northern Namibia, generally prefer a pre-paid water system, since it offers the opportunity to economise on water consumption and to control expenses, thus avoiding situations where bills cannot be paid and supplies are cut. However, communal taps frequently break down, often due to misuse. Repair work is slow, often requiring spare parts that are not available in the country. In January 2004, for instance, Ondangwa Town Council ran twenty-five communal taps with pre-paid cards, ten of which did not work due to damage caused by vandalism. Residents relying on communal taps complained that vandals are usually non-residents.

In order to avoid heavy reliance on unreliable communal taps, residents of the informal settlements have been calling for private taps with a pre-paid system, which was then only available in the formal settlements. Lacking this option, many residents of the informal settlements instead chose to pool resources and share a private tap connection, even though it was not pre-paid. In this system, three or more households shared one private tap connection, located in and ascribed to one of the participating households. Sharing the bill, that is, paying equal shares of the connection fees and the expenses related to water usage, reduced the average costs for each household. More importantly, it decreased the risk of disconnection due to non-payment, since all parties had an interest in keeping the supply running. Members in the arrangement who repeatedly failed to contribute to the water bills were eventually excluded. The concomitant loss of an assured water-source represented an effective regulatory and enforcing mechanism.

Source: Fjeldstad et al (2005). 
An increasing amount of evidence suggests that the rate of contribution to a public good is affected by factors such as citizens' trust in others, and the trustworthiness of the government (Slemrod 2003). Without trust there is little basis for social cooperation and voluntary compliance with laws and regulations that could potentially benefit everyone. In particular, three dimensions of trust seem to affect citizens' compliance: (1) trust in the local government to use revenues to provide expected services; (2) trust in local government to establish fair procedures for revenue collection; and (3) trust in other citizens to pay their share. The larger the fraction of the local population that is observed not paying, the lower is the perceived risk of being prosecuted. This has an impact on the individual ratepayer's perception of the credibility and trustworthiness of the revenue administration. Moreover, the attitude of local political leaders with respect to payment seems to be important, for example, by legitimising non-payment through their own behaviour. This suggests that there are reasons and scope for innovation.

The problems of non-payment should therefore be attacked on several fronts, including service delivery, better administration and payment schemes, and community involvement (Fjeldstad 2004). To achieve this, in-depth knowledge and data are required on payment levels for each ward, the proportion of municipal accounts delivered, the number and type of complaints received, living conditions for the poorest segments of the population, including the elderly and unemployed, etc. Moreover, customer care must show that complaining will bring results. Citizens should be encouraged to report faults, such as leaking taps or streetlights not functioning. The prompt redress of such complaints may help convince people that the municipality means business. Furthermore, citizens' involvement in identifying problems and setting priorities may generate a greater sense of community involvement. Initially, it might be advisable to link payment directly to visible improvements in services. Finally, if local government officials, councillors, and community leaders were to cooperate in setting common goals, it might help develop trust.

\section{Local government tax collection practices}

Local government authorities commonly experience difficulty in collecting taxes, fees and charges. Thus, there are many experiments to find ways of making tax collection produce more revenue. Practices for collection of local taxes range from cases where local government authorities collect taxes themselves, to cases where tax collection is outsourced to the central government, private agents, or semi-private partners, such as when market cooperatives or private companies collect tax on behalf of the local government.

Some taxes and fees are collected by the government and channelled back to the local government. In Malawi the non-tax revenue is collected by the central government, before the resources are redistributed to District Assemblies using a formula approved by the Cabinet (Malawi Government 1998). A less typical example is from Tanzania, where the collection of property tax in Dar es Salaam is assigned to the Tanzania Revenue Authority (Fjeldstad et al 2011).

In Tanzania, collection of a large number of local government revenue sources has been outsourced in recent years (Fjeldstad et al. 2009b). They include private collection of property taxes in some urban councils; market fees in both rural and urban councils; forestry levies (until 2005) mainly in rural councils; cess on certain agricultural products in rural councils; bus stand and parking fees. In Mwanza City Council, for instance, private agents collected more than one-third of the council's own revenue in 2006. 
Revenue collection is outsourced to a range of different types of agents within and across councils. Another example from Mwanza City Council shows how the collection of fish market fees was outsourced to a fish dealer organisation, and the collection of fees at the central market was contracted to a vegetable cooperative operating in the market. In Kilosa District Council the collection of forest levies (until they were abolished in 2005) was outsourced to a private company, whose main activity was to run private schools. Iringa District Council contracted village councils to collect revenue from village businesses.

Evidence is inconclusive as to whether outsourcing has led to better revenue administration performance compared to when tax collection remains a function of local government officials. However, outsourcing can establish a platform from which change can be facilitated, but its initial impact and longer-term successful performance depend on:

- the strength and quality of the management of the local government authority;

- political commitment to support the reform; and

- transparency, reflected in the provision of accessible and updated information to the general public on the tendering process and bids received, as well as data on the revenue potential and actual collection (Fjeldstad et al 2010a).

A major challenge facing privatised revenue collection in local government authorities is to assess the revenue potential for various tax bases. Usually revenue assessment is conducted on an ad hoc basis, often based on the previous year's reported collection. Substantial underestimation of the revenue potential may imply that actual collection by the agent is substantially higher than what is reflected in the contract. Consequently, there is a risk of ending up in a situation where the agent keeps a substantial portion of the revenue collected; this already seems to be the case in some councils. In a study from Uganda, Iversen et al (2006) found substantial gaps between the local government estimates of the revenue yields from local markets with the actual revenue yield collected by private agents (see Figure 3). In six markets studied, the gaps (lost revenues) amounted to between 25 per cent and 74 per cent of total revenue collected in each market. Moreover, the actual gross margins realised by private agents caused by this undervaluation of market yields varied between 71 per cent and 970 per cent. Thus, it seems evident that rather than enhancing local revenue, the private tax collection system in Uganda transfers money from ordinary and often poor rural taxpayers into the pockets of private tax agents and their various associates. On average, 53 per cent of all revenue collected from vendors in the markets could be interpreted as pure redistributive transfers to members of the local elite. 
Figure 3: Rents in tendering contracts for a rural market in Uganda

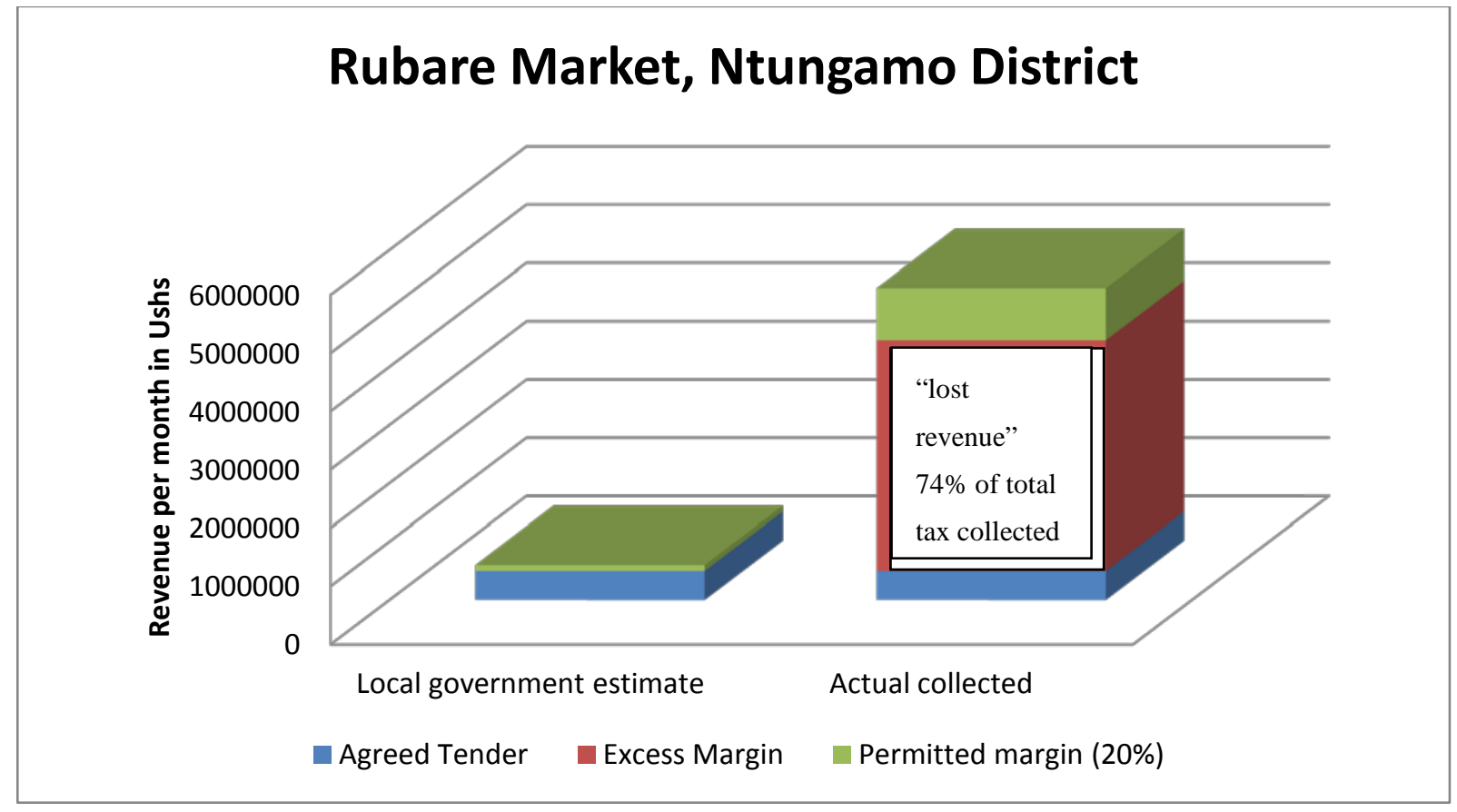

Source: Iversen et al. (2006: 324).

There are examples suggesting that public officials are more effective as revenue collectors than their private alternatives. For instance, over a two-year period Temeke municipal staff in Dar es Salaam added about 80,000 properties to the municipality's flat tax property register at the cost of less than USD 1 per property. During the same period, private consultants who were engaged by the municipality added only 5,000 properties at a cost of USD 17 per property (Franzsen 2007:10-11).

\section{Concluding remarks and tentative implications for policy}

Despite major reforms of the central government tax system during the last two decades, local government tax systems remain largely neglected. This study shows that the local tax systems often are distortive, costly to administer, and exacerbate inequity. Generally, little or no coordination with respect to taxation is observed between various levels of government. This has partly to do with lack of capacity at all levels. This has led to double taxation of the same revenue base, as well as inconsistencies between local and central government tax policies. In some countries, local governments impose high taxes on export crops, inconsistent with the national government's policy to encourage export production. Furthermore, while central government taxes affect only relatively few people directly, local government taxation affects many more. Local government taxation is therefore central to a better understanding of state-citizen relations.

While the current potential for most rural councils to raise substantial own revenue is limited, the potential for revenue enhancement in urban councils is better. However, one major administrative problem today for many urban councils in anglophone Africa is their inability to collect all the revenue due to them. There are huge gaps between reported and projected revenues, particularly in many municipalities. This is due to: (1) poor administrative capacity 
to assess the revenue base; (2) poor administrative capacity to enforce the payment of taxes; (3) explicit and intentional tax evasion and resistance from taxpayers; (4) corruption, including embezzlement of revenues; (5) external pressure on the local finance department to provide optimistic projections; and (6) political pressure on the local tax administration to relax revenue collection, especially during election periods. In this setting, fundamental issues to be addressed in the context of local government fiscal reforms are to redesign the current revenue structure and to strengthen financial management. In addition, measures are required to enhance taxpayers' compliance and to improve the accountability of revenue collectors and elected councillors. This cannot be achieved without substantial and consistent political support from the central government.

Improved information supplied to the public on budgets and accounts may improve the opportunities for citizens to exercise their voice and demand accountability from local authorities. This is among the lessons we can draw from decentralisation reform in Uganda (Reinikka and Svensson 2002). It is, however, important to stress that encouraging citizens and civil society to engage in fiscal and financial monitoring at the local level does not imply that such measures should replace formal auditing and accounting mechanisms. Nor does it imply that such measures will weaken the formal accountability mechanisms. On the contrary, it can strengthen the legitimacy and standing of local government authorities in the communities by contributing complementary measures to improve the control of revenue collection and expenditure.

A fundamental requirement when redesigning the local revenue system is greater emphasis on the cost-effectiveness of revenue collection, taking into account not only the direct costs of tax administration, but also the overall costs to the economy, including the compliance costs to taxpayers. In addition, losses through corruption and tax evasion need to be reduced. To achieve these aims, there is a need to simplify the business licence and fee structures by reducing the number of rates and coverage. Moreover, local taxes and licences should be harmonised with central government tax bases, to avoid double taxation and conflicts with national development policies, such as job creation and private sector development (Pimhidzai and Fox 2011). The experiences from Kenya with the one-stop-shop Single Business Permit systems are promising for future reforms.

More realism is also required when it comes to the implementation of a well-functioning property tax system. An important element of the fiscal decentralisation process in many countries has been to give municipalities the power to value, assess, bill, collect, and enforce property taxes. Property tax has many attractions as a local revenue base since it is imposed on immobile assets and therefore is difficult to avoid - at least in principle. However, it has some obvious weaknesses that need to be taken into consideration before heavy reliance is placed on it. In particular, problems of valuation and tax enforcement often occur due to political intervention and administrative weaknesses. The municipalities' capacity and capability to administer the property tax have in general proved to be inadequate. It has been difficult for many municipalities across Africa to maintain the current property valuation registers, let alone continue the property valuation initiatives. It is therefore necessary to reassess the basis of the property tax in urban councils and to implement a simpler and more coherent approach to valuation provision, taking into consideration administrative capacity and capability constraints facing the urban councils. A pragmatic policy approach is required, which may imply centralisation of certain issues, such as management of property titles, valuation assessments, etc.

Local own revenue is a necessary but not a sufficient condition for fiscal decentralisation. In most local government authorities in Africa, local sources are generally not sufficient to develop and supply adequate services for the fast-growing population. The reality is that most local government authorities in anglophone Africa will continue to be heavily dependent on fiscal transfers from the central government for a long time. Only a few large urban 
governments located in rich areas are able to finance a substantial proportion of their total expenditure with their own revenue sources. Transfer systems based upon revenue sharing between the central and subnational levels of government and grants from the central level should therefore be considered important components of fiscal decentralisation programmes.

\section{Issues for further research}

Based on the knowledge gaps identified in this study, we suggest below areas for further research on local government taxation in anglophone Africa. Both technical and political economy questions are under-explored in the literature. Combining research on the technical administrative framework for local taxation with the political and economic realities at the local and central level has the potential to identify constraints and practices that can guide policy work, and be used as benchmarks to assess actual policy implementation.

Financial transfers from the centre are typically important components of local government revenue. How does this impact on local government fiscal autonomy, which typically is formulated as a key objective of local tax reforms? A series of research questions related to reform is suggested for further research:

- How should effective revenue-raising systems for subnational governments be designed and implemented? This issue, and the distinction between urban and rural councils in particular, has received limited attention in the literature.

- What are the actual fees, levies and taxes imposed locally compared to those officially stated in policy documents and in reform plans?

- How do local government revenue reforms affect taxpayers? This should be investigated using time series with surveys immediately after, one year and three years after the reform.

Some research finds that taxpayers perceive local governments to be more trustworthy and accountable than higher levels of government, while other findings point at the frail links between local revenue-raising and the responsiveness of African local governments. Existing research is neither conclusive nor extensive. We have therefore identified the following questions addressing local government accountability:

- Is there a connection between local tax payment and service delivery? Is there any evidence on how partnerships (private, public, donor and local government) can result in more effective and sustainable local revenue mobilisation?

- Where do we find examples that prove a link between local taxation and expanded responsiveness and accountability?

- Are there good practices from private tax collection concerning taxpayer education, accountability and revenue raising?

An entry point to assess these questions will be through case studies of fiscal reforms in selected municipalities in Africa.

Local government own revenue primarily comes from property tax, business licences and user fees. Currently the Lincoln Institute of Land Policy and the Africa Tax Institute (ATI) are conducting a comprehensive research programme that aims to collect and systematise data on the present status and future prospects of property-related taxes in all 54 African countries, with a primary focus on land and building taxes and real estate transfer taxes. Since the political economy analysis of land and property taxes is not explicitly addressed in this programme, we will explore the possibility to partner with the Lincoln Institute and ATI to 
conduct complementary research on property taxation. In-depth political economy analysis of business licences may contribute to gaining valuable insights on entrepreneurship, incentives and the rights of small business owners. The World Bank's Doing Business reports (2010a, b) have some data on this, but they only cover a limited number of countries and provide little background detail on the data. Finally, research suggests that citizens will be more willing to pay tax when there is a direct link between payment and service provision (quid pro quo). More research is needed to better understand the earmarking of taxes for specific purposes and whether (and under what conditions) user fees/service charges can become efficient local revenue sources.

Collection methods vary substantially between local government authorities within and across anglophone Africa. In some countries, e.g. in Tanzania and Uganda, local governments have outsourced revenue collection of some taxes to private agents. Evidence is inconclusive on what collection methods work under what conditions, and how local governments can best manage the different collection methods. Some suggestions for further research will focus on private revenue collection:

- Which revenue bases are outsourced and why these?

- Which allowances and incentive systems exist for private collectors?

- What are the revenue trends from different sources after outsourcing compared to the pre-outsourcing period?

Future research should focus on building a more extensive empirical knowledge on the technical, economic and political dimensions of local government taxation. More broadly, the suggestions for further research in this paper focus on the politics of successful tax reform, new insights about taxation and growth, and on the connection between tax governance and state building at the local level. Donors will potentially benefit from the research topics suggested here, by getting policy relevant advice on how to support local government taxation more effectively. 


\section{References}

Ahmad, E. (1997) 'Intergovernmental Transfers - an International Perspective', in E. Ahmad (ed), Financing Decentralized Expenditures. An International Comparison of Grants, Cheltenham: Edward Elgar

Ajam, T. (2001) 'Intergovernmental Fiscal Relations in South Africa', in N. Levy and C. Tapscott (eds), Intergovernmental Relations in South Africa. The Challenges of Cooperative Government, Cape Town: IDASA/School of Government, University of the Western Cape

Araujo-Bonjean, C. and Chambas, G. (2003) Taxing the Urban Unrecorded Economy in subSaharan Africa, paper prepared for the 'Hard to Tax' conference, Atlanta, May 2003, CERDI-Université d'Auvergne, Clermont, France

Bahiigwa, G., Ellis, F., Fjeldstad, O-H. and Iversen, V. (2004) Rural Taxation in Uganda: Implications for Growth, Income Distribution, Local Government Revenue and Poverty Reduction, EPRC Research Series No. 35 (January), (Kampala: Economic Policy Research Centre)

Bahl, R. \& Bird, R. (2008) 'Subnational Taxes in Developing Countries: The Way Forward', Public Budgeting \& Finance, Vol. 28(4), pp. 1-25

and Smoke, P. (eds) (2003) Restructuring Local Government Finance in Developing Countries. Lessons from South Africa, Cheltenham: Edward Elgar

and Solomon, D. (2003) 'Overview of the Local Government Revenue System', in R. Bahl \& P. Smoke (eds) Restructuring Local Government Finance in Developing Countries. Lessons from South Africa, Cheltenham: Edward Elgar

— and Wallich, C. (1992) Intergovernmental fiscal relations in China, Policy Research Department Working Papers, Washington DC: World Bank

Bardhan, P. and Mookherjee, D. (2002) Corruption and Decentralization of Infrastructure in Developing Countries, mimeo, Univ. of California, Berkeley, and Boston University

Baskin, M. (2010) Constituency Development Funds (CDFs) as a Tool of Decentralized Development, overview paper presented the 56th Commonwealth Parliamentary Conference, 10-19 September, Nairobi

Beall, J. (2000) 'From the Culture of Poverty to Inclusive Citizens: Re-framing Urban Policy and Politics', Journal of International Development, 12: 158-181

Bell, M. E. and Bowman, J. H. (2006) Implementing a local property tax where there is no real estate market. The case of commonly owned land in rural South Africa, Cambridge: Lincoln Institute of Land Policy

Bird, R. (2010) Subnational Taxation in Developing Countries: A Review of the Literature, Policy Research Working Paper 5450, Washington DC: World Bank

_ (2001) 'User Charges in Local Government Finance', in R. Stren and M.E. Freire (eds), The Challenge of Urban Government, Washington: World Bank Institute

_ (1990) 'Intergovernmental Finance and Local Taxation in Developing Countries: Some 
Basic Considerations for Reformers', Public Administration and Development, 10: 277-288

_ and Slack, E. (2002) Land and Property Taxation: A Review, mimeo, University of Toronto

and Smart, M. (2002) 'Intergovernmental Fiscal Transfers: Lessons from International Experience', World Development, 30.6: 899-912

and Vaillancourt, F. (eds) (1998) Fiscal Decentralization in Developing Countries, Cambridge: Cambridge University Press

Boadway, R.W. and Shah, A. (2009) Fiscal Federalism, New York: Cambridge University Press

— Roberts, S. and Shah, A. (2000) 'Fiscal Federalism Dimensions of Tax Reform in Developing Countries', in G. Perry, J. Whalley and G. McMahon (eds), Fiscal Reform and Structural Change in Developing Countries, Vol. 1, Basingstoke: Macmillan Press

Boex, J. (2009) Fiscal Decentralization and Intergovernmental Finance Reform as an International Development Strategy, IDG Working Paper No. 2009-06, Washington DC: The Urban Institute Center on International Development and Governance

_ (2003) 'The Incidence of Local Government Allocations in Tanzania', Public Administration and Development, 23: 381-391

— and Martinez-Vazquez, J. (2006) Local Government Finance Reform in Developing Countries: The Case of Tanzania, Basingstoke: Palgrave Macmillan

Brosio, G. (2000) Decentralization in Africa, paper prepared for the Africa Department, International Monetary Fund, Washington DC: International Monetary Fund

Brun, J-F., Chambas, G. and Fjeldstad, O-H. (2012) Local government taxation in Africa, paper prepared for ICTD (draft), Brighton: International Centre for Tax and Development

Burgess, R. and Stern, N. (1993) 'Taxation and development', Journal of Economic Literature 31: $762-830$

Chitembo, A. (2009) Fiscal Decentralisation: A Comparative Perspective, Civil Society Representatives Sitting on the Zambian National Constitutional Conference (NCC), Lusaka

Cooksey, B. \& Mmuya, M. (1997) The use and quality of health services in rural Tanzania, Working Paper 6: 97, Dar es Salaam: TADREG

Derichs, A. and Einfeldt, C. (2006) Fiscal Decentralisation and Intergovernmental Fiscal Relations in South Africa, Strengthening Local Governance Programme, Eschborn: GTZ

Devas, N. (2003) 'Can City Governments in the South Deliver for the Poor: A Municipal Finance Perspective', International Development Planning Review, 25.1: 1-29

_ and Kelly, R. (2001) 'Regulation or Revenues? An Analysis of Local Business Licences, with a Case Study of the Single Business Permit Reform in Kenya', Public 
Administration and Development, 21: 381-391

Dillinger, W. (1991) Urban Property Tax Reform: Guidelines and Recommendations, Urban Management Programme Tool, Washington DC: The World Bank

Doing Business (2010a) Doing business in Nigeria. Subnational series, Washington DC: IFC, World Bank Group

(2010b) Doing business in Kenya. Subnational series, Washington DC: IFC, World Bank Group

Enemuo, F. C. (2000) 'Problems and Prospects of Local Governance', in G. Hyden, D. Olowu and H. Ogendo (eds), African Perspectives of Governance, Trenton/Asmara: Africa World Press

Farvacque-Vitkovic, C. and Godin, L. (1998) The future of African cities: challenges and priorities for urban development, Washington DC: World Bank <http://go.worldbank.org/7QJTRAD802>

Fjeldstad, O-H. (2006) 'Local Revenue Mobilization in Urban Settings in Africa', in Karin Millett, Dele Olowu and Robert Cameron (eds), Local governance and poverty reduction in Africa, Joint Africa Institute (AfDB, IMF and WB)

(2004) 'What's Trust Got To Do With It? Non-payment of Service Charges in Local Authorities in South Africa', The Journal of Modern African Studies, 42.4: 539-562

- (2001) 'Taxation, coercion and donors. Local government tax enforcement in Tanzania', The Journal of Modern African Studies, 39.2: 289-306

_ and Heggstad, K. (2011) The tax systems in Mozambique, Tanzania and Zambia: Capacity and constraints, CMI Report, R2011: 3, Bergen: Chr. Michelsen Institute

Piracha, M. and Magongo, J. (2011) The Political Economy of Property Tax Collection in Tanzania, paper prepared for the International Centre for Tax and Development, September (draft)

Katera, L., Msami, J. and Ngalewa, E. (2010a) Local Government Finances and Financial Management in Tanzania: Empirical evidence of trends 2000-2007, REPOA Special Paper No. 10-2010 (October), Dar es Salaam: Research on Poverty Alleviation

and Ngalewa, E. (2010b) Planning in Local Government Authorities in Tanzania: Bottom-up Meets Top-down, REPOA Brief No. 18 (January), Dar es Salaam: Research on Poverty Alleviation

(2009a) Maybe we should pay taxes after all? Citizens' changing views of taxation in Tanzania, REPOA Special Paper No. 29-2009 (April), Dar es Salaam: Mkuni Na Nyota Publishers, Research on Poverty Alleviation

(2009b) Outsourcing revenue collection to private agents: experiences from local government authorities in Tanzania, REPOA Special Paper No. 28-2009 (April), Dar es Salaam: Mkuni Na Nyota Publishers

and Therkildsen, O. (2008) 'Mass taxation and state-society relations in East Africa', in D. Braütigam, O-H. Fjeldstad and M. Moore (eds), Taxation and State Building in 
Developing Countries, Cambridge: Cambridge University Press

_ and Geisler, G., Nangulah, S., Nygaard, K., Pomuti, A., Shifotoka, A. and Van Rooy, G. (2005) Local Governance, Urban Poverty and Service Delivery in Namibia, CMI Report 12:2005 (Bergen: Chr. Michelsen Institute)

with Henjewele, F., Mwambe, G., Ngalewa, E. and Nygaard, K. (2004) Local Government Finances and Financial Management in Tanzania. Observations from Six Councils, 2000-2003, REPOA Special Paper No. 16, Dar es Salaam: Research on Poverty Alleviation

and Semboja (2000) 'Dilemmas of Fiscal Decentralisation. A Study of Local Government Taxation in Tanzania', Forum for Development Studies, 27.1: 7-41

Franzsen, R. (2007) 'Property Taxation in Anglophone Africa', Land Lines (April), Lincoln Institute of Land Policy

Franzsen, R. and Youngman, J. M. (2009) 'Mapping property taxes in Africa', Land Lines, Lincoln Institute of Land Policy

Gamser, M. (2003) Improving the Business Trade Licensing Reform Environment. A Contribution to WDR 2005 on Investment Climate, Growth and Poverty, London: Department for International Development

Iversen, V., Fjeldstad, O-H., Bahiigwa, G., Ellis, F. and James, R. (2006) 'Private tax collection - Remnant of the past or a way forward? Evidence from rural Uganda'. Public Administration and Development, 26: 317-328

Jibao, S.J. (2009) Property Taxation in Anglophone West Africa: Regional Overview, Working Paper WP09AWA1, Lincoln Institute of Land Policy

Juul, K. (2006) 'Decentralization, local taxation and citizenship in Senegal', Development and Change 37.4: 821-46

Malawi Government (1998) Malawi Decentralization Policy, Lilongwe: Government of Malawi

Martinez-Vázques, J. and Smoke, P. (2010a) 'Introduction', in Local government finance: the challenges of the 21st century. Second Global Report on Decentralization and Local Democracy, Barcelona: United Cities and Local Governments

_ _ (2010b) 'Conclusion', in Local government finance: the challenges of the 21st century. Second Global Report on Decentralization and Local Democracy, Barcelona: United Cities and Local Governments

— McLure C. and Vaillancourt, F. (2006) 'Revenues and expenditures in an intergovernmental framework', in R. M. Bird and F. Vaillancourt (eds), Perspectives on Fiscal Federalism, Washington: World Bank Institute

McCluskey, W. and Franzsen, R. (2005) An Evaluation of the Property Tax in Tanzania: An Untapped Fiscal Resource or Administrative Headache? Property Management, 23.1: 45-69

— J Johnstone, T. and Johnstone, D. (2003) Property Tax Reform: The Experience of Tanzania, London: RICS Foundation 
McDonald, D. A. and Pape, J. (eds) (2002), Cost Recovery and the Crisis of Service Delivery in South Africa, Cape Town/London: HSRC Publishers/ZED Books

McLure, C. E. Jnr. (1999) The Tax Assignment Problem: Conceptual and Administrative Considerations Achieving Subnational Fiscal Autonomy, Washington DC: World Bank Institute

Mikesell, J. (2002) International Experiences with Administration of Local Taxes: A Review of Practices and Issues, mimeo, School of Public and Environmental Affairs, Indiana University

Misch, F., Koh, H-J. and Paustian, N. (2011) SME Taxation in Zambia, October, Lusaka: Deutsche Gesellschaft für Internationale Zusammenarbeit

Mugabi, E. (2004). 'Uganda's decentralization policy, legal framework, local government structure and service delivery', in The First Conference of Regional Assemblies of Africa and Europe, Florence, September 17-18, 2004

Musgrave, R. (2000) Public Finance in a Democratic Society. Volume III The Foundations of Taxation and Expenditure, Cheltenham: Edward Elgar

Oates, W. E. (2005) 'Toward a Second-Generation Theory of Fiscal Federalism', International Tax and Public Finance (August), 12: 349-374

(1998) 'Comments on "Fostering Fiscally Responsive and Accountable Governance: Lessons from Decentralisation" by Shah', in R. Picciotto and E. Wiesner (eds), Evaluation \& Development. The Institutional Dimension, New Brunswick/London: Transaction Publishers

- (1972) Fiscal Federalism, New York: Harcourt Brace Jovanovich

Olowu, D and Wunsch, J.S. (2003) Local Governance in Africa: The Challenges of Democratic Decentralization, Boulder: Lynne Rienner

Pimhidzai, O. and Fox, L. (2011) Taking from the poor or local economic development: the dilemma of taxation of small informal enterprises in Uganda, paper prepared for the World Bank Africa Regional Project on Improving the Productivity and Reducing Risk of Household Enterprises, Washington DC

Prichard, W. (2010) Taxation and State Building: Towards a Governance Focused Tax Reform Agenda, IDS Working Paper 341, Brighton: Institute for Development Studies

Reinikka, R. \& Svensson, J. (2002) Assessing Frontline Service Delivery, Washington DC: Development Research Group, World Bank <http://www.worldbank.org/wbi/governance/assessing/pdf/reinikka.pdf>

Rondinelli, D., McCullough, J. and Johnson, R.W. (1989) 'Analysing Decentralization Policies in Developing Countries: A Political-economy Framework', Development and Change 20: $57-87$

Sander, C. (2003) Less is More. Better Compliance and Increased Revenues by Streamlining Business Registration in Uganda, A Contribution to World Development Report 2005 Investment Climate, Growth and Poverty, Bannock Consulting

Semboja, J. and Therkildsen, O. (eds) (1995) Service provision under stress in East Africa, 
London: James Currey

Shah, A. (1998) 'Fostering Fiscally Responsive and Accountable Governance: Lessons from Decentralisation', in R. Picciotto and E. Wiesner (eds), Evaluation \& Development. The Institutional Dimension, New Brunswick/London: Transaction Publishers

Skinner, J. (1993) 'If Agricultural Land Taxation Is So Efficient, Why Is It So Rarely Used?', in K. Hoff, A. Braverman and J. Stiglitz (eds), The Economics of Rural Organization: Theory, Practice, and Policy, Oxford: Oxford University Press

Slemrod, J. (2003) 'Trust in Public Finance', in S. Cnossen and H-W. Sinn (eds), Public Finance and Public Policy in the New Century, Cambridge, Mass: MIT Press

Steffensen, J. and Tidemand, P., with Naitore, H., Ssewankambo, E. and Mwaimpopo, E. (2004) A comparative analysis of experiences from decentralization in Kenya, Tanzania and Uganda. Synthesis report, Nordic Consulting Group for the World Bank

Tanzi, V. (2000) 'Fiscal Federalism and Decentralization: A Review of Some Efficiency and Macroeconomic Aspects', in V. Tanzi, Policies, Institutions and the Dark Side of Economics, Cheltenham: Edward Elgar

Ter-Minassian, T. (1999) 'Decentralisation and Macroeconomic Management', in K. Fukasaku and L.R. de Mello Jnr. (eds), Fiscal Decentralisation in Emerging Economies. Governance Issues, Paris: Development Centre of the Organisation for Economic Cooperation and Development

United Republic of Tanzania [URT] (2011) Speech by the Minister for Finance Hon. Mustafa Haidi Mkulo (MP), Introducing to the National Assembly the estimates of government revenue and expenditure for the financial year 2011/2012, Dar es Salaam: Government Printer

(2005) The Framework for the Financing of Local Government Authorities in Tanzania, policy paper on local government finance (draft, April), Dar es Salaam: President's Office - Regional Administration and Local Government/Ministry of Finance

__ (2003) Analytical Report: Dar es Salaam Revenue Study, Dar es Salaam

USAID (2005) Removing barriers to formalization: the case for reform and emerging best practice, March, Washington DC

World Bank (2000) Entering the 21st Century. World Development Report 1999/2000, New York: Oxford University Press for the World Bank

Yatta, F. and Vaillancourt, F. (2010) 'Africa', in Local government finance: the challenges of the 21st century, Second Global Report on Decentralization and Local Democracy, Barcelona: United Cities and Local Governments 


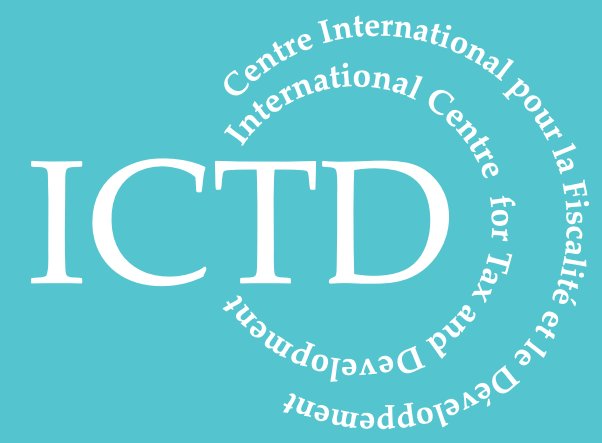

International Centre for Tax and Development at the Institute of Development Studies

Brighton BN1 9RE, UK

T: +44 (0)1273606261

F: $+44(0) 1273621202$

E: info@ictd.ac

www.ictd.ac 